
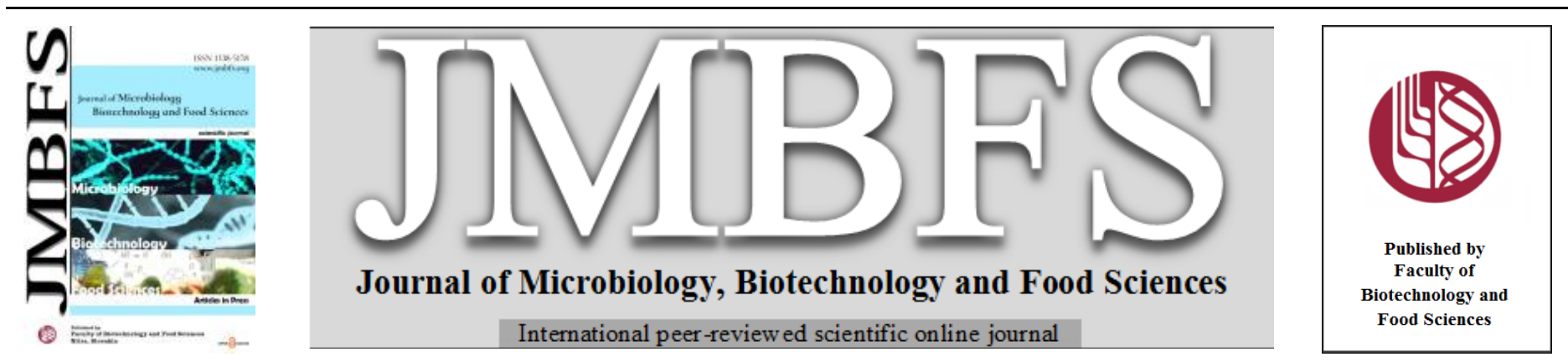

\title{
ISOLATION AND IDENTIFICATION OF A NEW ANTIPROLIFERATIVE INDOLOCARBAZOLE ALKALOID DERIVATIVE EXTRACTED FROM FARMED SHRIMP (Litopenaeus vannamei) MUSCLE
}

\author{
Joel Said García-Romo ${ }^{I}$, Martín Samuel Hernández-Zazueta ${ }^{1}$, Alma Carolina Galvez-Iriqui ${ }^{1}$, Maribel Plascencia-Jatomea ${ }^{1}$, María \\ Guadalupe Burboa-Zazueta ${ }^{2}$,Edgar Sandoval-Petris ${ }^{2}$, Rosario Maribel Robles-Sánchez ${ }^{1}$, Josué Elías Júarez-Onofre ${ }^{3}$, Javier \\ Hernández-Martínez ${ }^{4}$, Hisila Del Carmen Santacruz-Ortega ${ }^{5}$, Carmen María López-Saiz ${ }^{1}$, Armando Burgos-Hernández ${ }^{*}$
}

Address(es): Dr. Armando Burgos-Hernández,

${ }^{1}$ Departamento de Investigación y Posgrado en Alimentos, Universidad de Sonora, 83000 Sonora, México. Tel.: + 526-622-592-208; Fax: + 526-622-592-209.

${ }^{2}$ Departamento de Investigaciones Científicas y Tecnológicas, Universidad de Sonora, 83000 Sonora, México.

${ }^{3}$ Departamento de Física, Universidad de Sonora, 83000 Sonora, Mexico.

${ }^{4}$ Unidad de Servicios de Apoyo en Resolución Analítica, Universidad Veracruzana, 91190 Veracruz, México

${ }^{5}$ Departamento de Investigación en Polímeros y Materiales, Universidad de Sonora, 83000 Sonora, México.

*Corresponding author: armando.burgos@unison.mx

https://doi.org/10.55251/jmbfs.2173

\section{ARTICLE INFO}

Received 6. 10. 2019

Revised 22. 11. 2021

Accepted 7. 12. 2021

Published 1. 4. 2022

Regular article

OPEN $\bigodot_{\text {ACCESS }}$

\begin{abstract}
Farmed shrimp Litopenaeus vannamei, one of the most consumed seafood in the planet, is a source of antiproliferative extracts still to be fully characterized. This study the isolation and identification of these antiproliferative compounds. From a chloroform-soluble extract from shrimp muscle, hexane- and methanol-soluble fractions were obtained and tested for antiproliferative activity (MTT), a bioassay that guided the fractionation and isolation of bioactive fractions using open column chromatography. MeOH-soluble fraction resulted bioactive and was subjected to further fractionation from which one subfraction outstand for being highly active against prostate cancer cell line. Antiproliferative effects were evaluated using colorimetric assays and cell morphology observations. Further chromatographic procedures resulted in sub-fractions from which one was effective in causing DNA damage and F-actin polymerization, which suggests cellular collapse and apoptosis. According to the structural chemical characterization carried out, dioctyl phthalate, eicosapentaenoic acid, and an indolocarbazole alkaloid type of compound were identified. This last compound, which resulted majorly responsible for the bioactivity, was not found reported in the available databases. Pure EPA control was used to compare it with the subfraction, observing greater activity in the subfraction than when EPA was used, suggesting that another compound different from EPA is providing the highest activity; but, more investigation is needed for a full chemical and structural characterization.
\end{abstract}

Keywords: Litopenaeus vannamei, bioactive compounds, marine source

\section{INTRODUCTION}

Academic and pharmaceutical institutions have developed several chemotherapeutic compounds, but their efficacy and adverse effects are limitations for their use (Buzdar et al., 2005; DeVita \& Chu, 2008; Martin et al., 2014). Another problem in cancer chemotherapy is drug resistance (Austreid, Lonning, \& Eikesdal, 2014). Therefore, the search for more effective and safer bioactive molecules gains importance (Livstone, 2019).

The search for novel natural bioactive products is not an easy task; there are many challenges throughout the process of obtaining new effective and efficient drugs. Despite that, various organizations have decided to reduce mortality and morbidity rates through investigation on biologically active compounds from nature (De Kok, Van Breda, \& Manson, 2008; Thomson, LeWinn, Newton, Alberts, \& Martinez, 2003), and the search for these new molecules in the marine environment is each time more frequently considered. Nowadays, several studies have reported the existence of potential anticancer compounds (Lordan, Ross, $\boldsymbol{\&}$ Stanton, 2011; Stankevicins, Aiub, Maria, Lobo-Hajdu, \& Felzenszwalb, 2008), which include bacterial, fungal, but also higher animals including commonly consumed seafood; among them are shrimp species.

Shrimp, one of the top consumed seafood in the world, has been reported to contain potential anticancer compounds in its lipid fraction (López-Saiz et al., 2016; López-Saiz, Suárez-Jiménez, Plascencia-Jatomea, \& Burgos-Hernández, 2013; Wilson-Sanchez et al., 2010). Examples include carotenoids, which have been associated to apoptosis induction and oxidative stress promotion in cancer cells lines (Sila et al., 2013; Sowmya, Arathi, Vijay, Baskaran, \& Lakshminarayana, 2017). Also, hemocyanin has reported as a cancerous cellgrowth inhibitor and apoptosis inductor (Zheng et al., 2016), and to exert antitumorigenicity in in vivo studies (S. Liu et al., 2017).

Previously, a triglyceride esterified containing polyunsaturated fatty acids was reported to have the capability of inhibiting proliferation of a murine lymphoma cell line (López-Saiz et al., 2014); however, other biologically active fractions obtained during this study were also reported. Polyunsaturated fatty acids are well known for providing health benefits from seafood consumption, since they are present in significant amounts; however, other minoritarian compounds with great bioactivity have been detected and identified as interesting molecules that might be proposed for their chemical synthesis and further research as potentia chemotherapeutic agents. Recently, a highly chemoprotective indolocarbazole alkaloid type of compound, present in low concentrations in wild shrimp (Litopenaeus stylirostris), was reported (García-Romo et al., 2020). Based on the above, he present study aimed the characterization of these antiproliferative fractions previously reported in farmed shrimp Litopenaeus vannamei and to study the possible presence of the indolocarbazole alkaloid type of compound and the ways by which these molecules might act.

\section{MATERIALS AND METHODS}

Testing species

Farmed shrimp (Litopenaeus vannamei), acquired at Hermosillo, Sonora, México from a local market, was taken in ice to the University of Sonora seafood laboratory. Edible portions of shrimp (muscle) were separated and immediately processed for extraction according to reported procedure López-Saiz et al., (2014).

\section{Crude extraction and solvent partition}

Shrimp muscle (100 g) extraction and solvent partitioning procedures were conducted according to reported procedure López-Saiz et al., (2014), from which hexane- and methanol-soluble fractions were obtained and dried under $\mathrm{N}_{2}$ stream for further biological activity testing. All the studies performed in the present 
research work were carried out using shrimp cultured from the same culturing season.

\section{Column chromatography}

Methanol-soluble fraction was reconstituted again in methanol and was subjected to fractionation using open column chromatography to obtain same fractions reported by López-Saiz et al., (2014). All the fractions were tested to confirm their biological activity.

\section{Semi-preparative thin layer chromatography (TLC) and partial purification}

The fraction with the highest biological activity were further fractionated using silica gel-preparative TLC, using hexane-ethyl acetate (95:5) as a mobile phase (W. Liu et al., 2019). All the sub-fractions were evaluated for biological activity. For further purification of the most active compounds, undesired substances were eliminated by solvent partitioning.

\section{Cell lines}

Five cancerous- [A-549 (lung carcinoma), HCT116 (colon carcinoma), HeLa (epithelioid cervix carcinoma), MDA-MB-231 (breast adenocarcinoma), and 22Rv1 (prostate carcinoma)] and 1 non-cancerous [ARPE-19 (retinal pigmented epithelium)] human epithelial cell lines were used. Cells were cultured in Dulbecco's modified Eagle's medium (DMEM) and RPMI-1640 Medium (Sigma Aldrich, St. Louis, MO, USA), amended with 10 and $15 \%$ heat-inactivated fetal bovine serum (FBS) (Corning, NY, USA), respectively, and incubated in an atmosphere of $5 \% \mathrm{CO}_{2}$ at $37^{\circ} \mathrm{C}$.

\section{3-(4, 5-Dimethylthiazol-2-yl)-2, 5-Diphenyltetrazolium Bromide (MTT) assay}

Antiproliferative activity was evaluated using the MTT assay (Roche, cell proliferation kit I, Roche, Cat. No. 11-465-007-001), according to manufacturer's instructions. Briefly, $1 \times 10^{4}$ and $2 \times 10^{4}$ cells/well were suspended in $100 \mu \mathrm{L}$ DMEM or RPMI at $10-15 \%$ FBS, according to ATCC specifications (Boyd \& Paull, 1995); they were seeded on flat-bottom 96-well plates before being incubated $(24 \mathrm{~h})$. Then, cell were incubated in $100 \mu \mathrm{L}$ of medium amended with each of the samples (dissolved in DMSO) at different concentrations, diluted in supplemented medium at $10-15 \%$ of FBS, and incubated for another $48 \mathrm{~h}$ Control cultures consisted of cells in medium only (final DMSO concentrations: $0.06 \%-0.5 \% \mathrm{v} / \mathrm{v})$. After $4 \mathrm{~h}, 10 \mu \mathrm{L}$ of MTT $(5 \mathrm{mg} / \mathrm{mL})$ were added to every well, and a $100 \mu \mathrm{L}$ sodium dodecyl sulfate (SDS) aliquot was added to dissolve formazan crystals before the absorbance of each well was read (overnight) in an ELISA plate reader equipment (Benchmark Microplate Reader; Bio-Rad, Hercules, CA, USA). Test and reference wavelengths were 570 and $650 \mathrm{~nm}$, respectively. Cisplatin (CIS) (15663-27-1, Sigma-Aldrich) and docetaxel (DOC) (01885, Sigma-Aldrich) were used as positive antiproliferation controls. Dioctyl phthalate (DOP) (D201154, Sigma-Aldrich) and eicosapentaenoic acid (EPA) (E2011, Sigma-Aldrich) were used as confirmatory standards for selected bioactive fractions. To evaluate the growth behavior of the most sensitive cell line to a specific fraction, a cellular growth kinetic was made from 0 to $72 \mathrm{~h}$. Three independent assays were made, and all testing concentrations were assayed in triplicate (K. Liu, Xiao, Wang, Chen, \& Hu, 2017)

Phalloidin-tetramethylrhodamine B isothiocyanate and 4', 6-Diamidino-2phenyindole, dilactate fluorescence cell staining

To observe the effect of shrimp fractions on internal morphological/structura aspects of cell lines, staining procedures were performed according to Van Vuuren, Botes, Jurgens, Joubert, \& Van Den Bout, 2019, with modifications Testing cultures were incubated in 96-well microplates for $24 \mathrm{~h}$ and treated with sub-fractions at their $\mathrm{GI}_{50}$. With the aim of seeking the incubation time at which morphological changes cell can be observed, $3.7 \%$ formaldehyde in PBS was used to fix cells and $0.2 \%$ Triton X-100 in PBS was added for 15 min to permeabilize them, after $4,12,24$, and $48 \mathrm{~h}$. Then, phalloidin-tetramethylrhodamine B isothiocyanate (phalloidin) (Sigma-Aldrich, MFCD00278840) and 4', 6Diamidino-2-phenyindole, dilactate (DAPI) (Sigma-Aldrich, D9564) were used to stain cells and visualize F-actin and DNA, respectively. Microplates were placed onto a microscope (inverted epifluorescence, Leica DMi8) to carried out the observations.

\section{Ultraviolet-visible (UV-Vis) and fluorescence spectroscopies}

Bioactive subfraction was subjected to UV-Vis and fluorescence studies following the procedure described by García-Romo et al. (2020).

\section{Proton-nuclear magnetic resonance $\left({ }^{1} \mathrm{H}-\mathrm{NMR}\right)$}

Sample preparation and measurements were carried out as described by GarcíaRomo et al. (2020). TMS proton signal was used an internal standard to record chemical shifts (ppm).

\section{Electrospray ionization tandem mass spectrometry (ESI/MS)}

Mass spectrometry analyses on bioactive fraction was performed according to García-Romo et al. (2020).

\section{Statistical analysis}

An analysis of variance (ANOVA) along with the Tukey multiple comparisons test, with a confidence interval of $95 \%$ was used to analyze data (SPSS). A probit analysis was carried out to obtain $\mathrm{GI}_{50}$ values for bioactive fractions, using the Number Cruncher Statistical Software (NCSS), version 2001, NCSS Statistical Software, USA. Data is presented as the mean value \pm S.D. Data computation was made following procedures reported by the National Cancer Institute (NCI) National Institutes of Health (NIH). Developmental Therapeutics Program (DTP), Human Tumor Cell Line Screen Process (http://dtp.nci.nih.gov/branches/btb/ivclsp.html) and as described by Monks et al. 1991.

\section{RESULTS AND DISCUSSION}

\section{Extraction and fractions obtained}

Chloroform-soluble extract (yield of $5.58 \mathrm{~g} / \mathrm{kg}$ of shrimp muscle) was obtained from which two partitions were achieved: a hexane- and a methanol-soluble partitions. Methanol-soluble partition resulted bioactive and it was fractionated using open column chromatography, from which were obtained 15 packages of fractions, denominating them fraction $\mathrm{M}$ (methanol partition) $1-15$, whose yield (in $\mathrm{mg}$ per $\mathrm{g}$ of methanol partition) of each fractions are the following: $1,7.9 ; 2$, $23.5 ; 3,24.1 ; 4,15.4 ; 5,8.4 ; 6,11.9 ; 7,12.9 ; 8,10.9 ; 9,188.7 ; 10,401.5 ; 11,43.6$ $12,67.0 ; 13,76.7 ; 14,32.7 ; 15,23.6$. To localize the most antiproliferative compounds among the 15 fractions, they were tested against different human cancer cell line; then a sub-division (highest level of purity) of the most bioactive fraction (M.11), calls sub-fraction M.11.A, M.11.B, M.11.C, and M.11.D, where the $\%$ obtained was $30,10,60$ and 10 , respectively; once the present compounds were identified, a partial purification of bioactive sub-fraction, was carried out.

\section{Bioactivity-guided isolation of antiproliferative compounds}

The potential that sample must prevent the proliferation of cancerous cells is known as antiproliferative activity; detection of this bioactivity in all the fractions obtained was performed using the MTT assay and the selection of the most bioactive fractions was based on their half-maximal growth inhibition $\left(\mathrm{GI}_{50}\right)$ values, the lower this value the higher the bioactivity. As shown in Table 1, only methanol partition could reduce $\left(\mathrm{GI}_{50}\right.$ values of $\left.177 \pm 8 \mu \mathrm{g} / \mathrm{mL}\right)$ the proliferation of 22Rv1 cell line, without affecting a non-cancerous cell line (ARPE-19). Methanol partition was then fractionated resulting in 15 fractions, form which M.11, M.12, and M.15 showed antiproliferative activity on human cell line 22Rv1 (prostate cancer), with $\mathrm{GI}_{50}$ values of $70.6 \pm 5.8,71.0 \pm 4.5$, and $70.3 \pm 5.6 \mu \mathrm{g} / \mathrm{mL}$, respectively (Table 2). However, as shown also in Table 2, fraction M.11 was significantly $(\mathrm{P} \leq 0.05)$ more active against HeLa, MDA-MB-231, and A549 cell lines than the other 2 fractions, therefore it was selected for further fractionation.

Table 1 Half-maximal growth inhibition $\left(\mathrm{GI}_{50}\right)$ for crude extract and partitions obtained from farmed shrimp (Litopenaeus vannamei) muscle on human epithelial cell lines after $48 \mathrm{~h}$.

\begin{tabular}{|c|c|c|}
\hline & \multicolumn{2}{|c|}{$\mathrm{GI}_{50}(\mu \mathrm{g} / \mathrm{mL})$} \\
\hline & Cancerous cell & Non-cancerous cell \\
\hline & 22Rv1 & ARPE-19 \\
\hline Chloroform crude extract & $>200 \mathrm{~b}$ & $>200 \mathrm{a}$ \\
\hline Hexane partition & $>200 \mathrm{~b}$ & $>200 \mathrm{a}$ \\
\hline Methanol partition & $177 \pm 8 \mathrm{a}$ & $>200 \mathrm{a}$ \\
\hline
\end{tabular}

Values represent means \pm S.D. from 3 determinations. Distinct letters in a column are significantly different $(\mathrm{P} \leq 0.05)$. Control cultures were performed in DMSO $(0.5 \%)$ representing $100 \%$ proliferation. These values were statistically estimated from a dose response curve using concentrations of $200 \mu \mathrm{g} / \mathrm{mL}$ downwards. 
Table 2 Half-maximal growth inhibition $\left(\mathrm{GI}_{50}\right)$ for fractions obtained from column chromatography fractionation of the methanol-partition, on human cancer epithelial cell lines after $48 \mathrm{~h}$.

\begin{tabular}{|c|c|c|c|c|c|}
\hline & \multicolumn{5}{|c|}{$\mathrm{GI}_{50}(\mu \mathrm{g} / \mathrm{mL})$} \\
\hline & \multicolumn{2}{|c|}{ Adenocarcinomas } & \multicolumn{3}{|c|}{ Carcinomas } \\
\hline & HeLa & MDA-MB-231 & A549 & 22Rv1 & HCT116 \\
\hline M.1 & $>200 \mathrm{e}$ & $>200 \mathrm{e}$ & $172 \pm 16 \mathrm{~d}$ & $135 \pm 17 \mathrm{~cd}$ & $>200 \mathrm{e}$ \\
\hline M.2 & $>200 \mathrm{e}$ & $>200 \mathrm{e}$ & $86 \pm 10 b$ & $195 \pm 11 \mathrm{f}$ & $>200 \mathrm{e}$ \\
\hline M.3 & $>200 \mathrm{e}$ & $>200 \mathrm{e}$ & $>200 \mathrm{e}$ & $>200 \mathrm{f}$ & $>200 \mathrm{e}$ \\
\hline M.4 & $>200 \mathrm{e}$ & $>200 \mathrm{e}$ & $>200 \mathrm{e}$ & $>200 \mathrm{f}$ & $>200 \mathrm{e}$ \\
\hline M.5 & $>200 \mathrm{e}$ & $>200 \mathrm{e}$ & $>200 \mathrm{e}$ & $142 \pm 7 \mathrm{~d}$ & $>200 \mathrm{e}$ \\
\hline M.6 & $>200 \mathrm{e}$ & $148 \pm 10 \mathrm{~cd}$ & $>200 \mathrm{e}$ & $117 \pm 7 \mathrm{c}$ & $>200 \mathrm{e}$ \\
\hline M.7 & $>200 \mathrm{e}$ & $>200 \mathrm{e}$ & $>200 \mathrm{e}$ & $>200 \mathrm{f}$ & $>200 \mathrm{e}$ \\
\hline M.8 & $>200 \mathrm{e}$ & $>200 \mathrm{e}$ & $>200 \mathrm{e}$ & $>200 \mathrm{f}$ & $>200 \mathrm{e}$ \\
\hline M.9 & $>200 \mathrm{e}$ & $>200 \mathrm{e}$ & $167 \pm 11 \mathrm{~d}$ & $173 \pm 11 \mathrm{e}$ & $189 \pm 9 \mathrm{e}$ \\
\hline M.10 & $161 \pm 9 d$ & $>200 \mathrm{e}$ & $131 \pm 8 c$ & $84.0 \pm 6.2 b$ & $130 \pm 19 d$ \\
\hline M.11 & $144 \pm 13 \mathrm{c}$ & $101 \pm 10 b$ & $83.5 \pm 12.2 \mathrm{~b}$ & $70.6 \pm 5.8 b$ & $92.7 \pm 16 \mathrm{c}$ \\
\hline M.12 & $148 \pm 8 c$ & $132 \pm 6 \mathrm{c}$ & $174 \pm 13 d$ & $71.0 \pm 4.5 \mathrm{~b}$ & $112 \pm 16 \mathrm{~cd}$ \\
\hline M.13 & $>200 \mathrm{e}$ & $>200 \mathrm{e}$ & $>200 \mathrm{e}$ & $>200 \mathrm{f}$ & $>200 \mathrm{e}$ \\
\hline M.14 & $>200 \mathrm{e}$ & $>200 \mathrm{e}$ & $>200 \mathrm{e}$ & $>200 \mathrm{f}$ & $>200 \mathrm{e}$ \\
\hline M.15 & $>200 \mathrm{e}$ & $138 \pm 8 \mathrm{~cd}$ & $>200 \mathrm{e}$ & $70.3 \pm 5.6 b$ & $107 \pm 15 \mathrm{~cd}$ \\
\hline CIS & $47.1 \pm 3.8 b$ & $152 \pm 5 \mathrm{~d}$ & $33.6 \pm 2.6 \mathrm{a}$ & $21.6 \pm 2.4 \mathrm{a}$ & $61.2 \pm 5.1 b$ \\
\hline DOC & $10.9 \pm 3.6 \mathrm{a}$ & $21.0 \pm 3.5 \mathrm{a}$ & $18.5 \pm 2.6 \mathrm{a}$ & $24.1 \pm 6.6 \mathrm{a}$ & $12.8 \pm 2.4 \mathrm{a}$ \\
\hline
\end{tabular}

Table 3 Half-maximal growth inhibition $\left(\mathrm{GI}_{50}\right)$ for sub-fractions obtained from thin layer chromatography fractionation of fraction M.11, on human epithelial cell lines at $48 \mathrm{~h}$

\begin{tabular}{lccc}
\hline & \multicolumn{2}{c}{$\mathrm{GI}_{50}(\mu \mathrm{g} / \mathrm{mL})$} & Bioselective index \\
\cline { 2 - 3 } & \multicolumn{1}{c}{ Cancerous cell } & Non-cancerous cell & \\
\cline { 2 - 3 } & $22 \mathrm{Rv} 1$ & ARPE-19 & \\
\hline M.11.A & $134 \pm 11 \mathrm{c}$ & $>200 \mathrm{c}$ & $>1.48$ \\
M.11.B & $46.6 \pm 2.2 \mathrm{~b}$ & $>200 \mathrm{c}$ & $>4.29$ \\
- M.11.B.1 & $26.6 \pm 8.0 \mathrm{a}$ & $180 \pm 3 \mathrm{~b}$ & 6.77 \\
M.11.C & $>200 \mathrm{~d}$ & $>200 \mathrm{c}$ & --- \\
M.11.D & $>200 \mathrm{~d}$ & $>200 \mathrm{c}$ & -- \\
DOP & $>200 \mathrm{~d}$ & $>200 \mathrm{c}$ & -- \\
EPA & $58.3 \pm 10 \mathrm{~b}$ & $>200 \mathrm{c}$ & $>3.42$ \\
CIS & $21.6 \pm 2.4 \mathrm{a}$ & $184 \pm 15 \mathrm{~b}$ & 8.52 \\
DOC & $24.1 \pm 6.6 \mathrm{a}$ & $155 \pm 4 \mathrm{a}$ & 6.44 \\
\hline
\end{tabular}

Values represent means \pm S.D. from 3 determinations. Distinct letters in a column are significantly different $(\mathrm{P} \leq 0.05)$. Control cultures were performed in DMSO $(0.5 \%)$ representing $100 \%$ proliferation. Dioctyl phthalate (DOP) and eicosapentaenoic acid (EPA) were used as standard controls. Cisplatin (CIS) and docetaxel (DOC) were used as a positive antiproliferative control. (---) means "was not determined".
To reach a higher level of isolation of the bioactive compounds, fraction M.11 was carried out by TLC in 4 groups of compounds with different polarities, which were coded sub-fractions M.11.A, M.11.B, M.11.C, and M.11.D. As shown in Table 3, sub-fraction M.11.B, was the most bioactive against the 22RV1 cell line, with a $\mathrm{GI}_{50}=46.6 \pm 2.2 \mu \mathrm{g} / \mathrm{ml}$; shows that the fraction procedure increased the antiproliferative activity, since the $\mathrm{GI}_{50}$ value decreased from $70.6 \pm 5.8$ (in M.11) to $46.6 \pm 2.2 \mu \mathrm{g} / \mathrm{ml}$ (in M.11.B), making it more effective against prostate cancerous cell line.

\section{Characterization of sub-fraction M.11.B}

For chemical/structural characterization of fraction M.11.B, ${ }^{1} \mathrm{H}-\mathrm{NMR}$, UV-Vis, ESI/MS, and fluorescence were used. UV-Vis analysis showed that compounds present in M.11.B have maximum absorption at wavelength of 205, 223, and 274 $\mathrm{nm}$, these transitions are attributed to $\pi \rightarrow \pi *$, which are related to the aromatic structures (Fig. 3 A). In addition, two bands with low absorbance at 313 and 350 $\mathrm{nm}$ and associated to $\mathrm{n} \rightarrow \pi *$ transition were also observed. This kind of transitions are related to aromatics rings that have attached atoms with available electrons (e.g., $\mathrm{O}$ and N). The fluorescence study (Fig. 3 B) showed an emission band centered at $\lambda=311 \mathrm{~nm}$ when the sample was excited at $\lambda=250$ or $274 \mathrm{~nm}$, suggesting the presence of a single compound responsible for this emission. These results confirm the presence of aromatics rings present in the extract.
A)

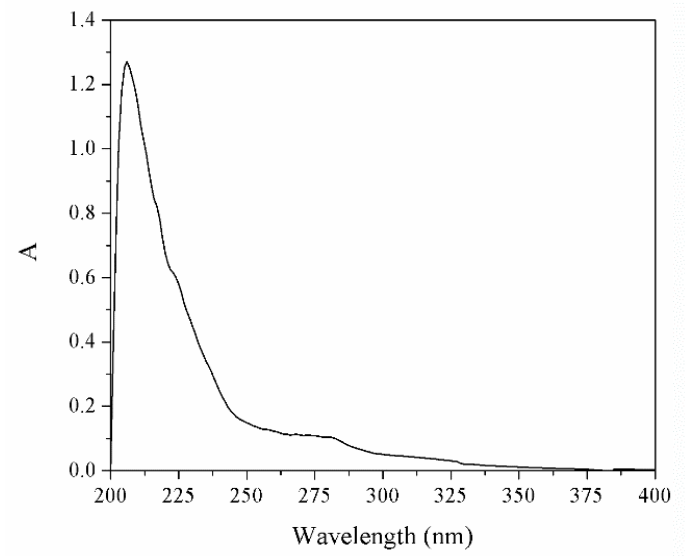

B)

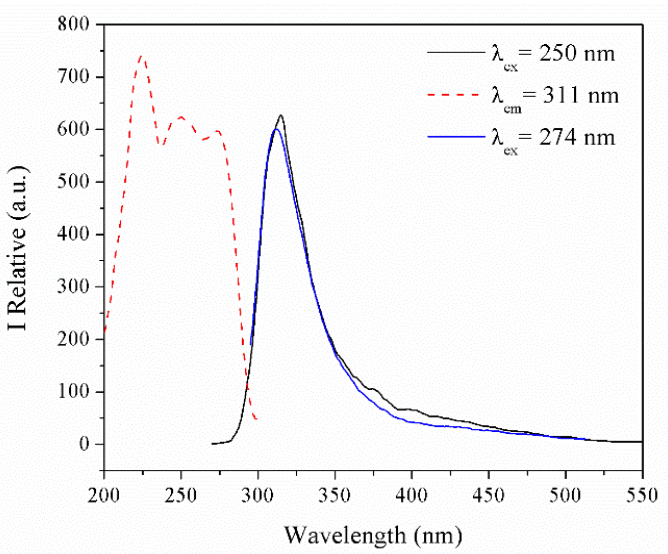

Figure 3 UV-Vis (A) and fluorescence (B) spectra of sub-fraction M.11.B diluted in methanol.

Results from ${ }^{1} \mathrm{H}-\mathrm{NMR}$ showed that M.11.B consists of more than one compound (Table 4). A characteristic pattern of 1,4 di-substituted aromatic ring $[\delta=7.71$ $\mathrm{ppm}(d d, \mathrm{~J}=5.7,3.3 \mathrm{~Hz})]$, protons of aromatic rings $[7.53 \mathrm{ppm}(d d, \mathrm{~J}=5.7,3.3$ $\mathrm{Hz}$ )], signals obtained at $\delta$ of $4.22 \mathrm{ppm}$ (associated to $\mathrm{O}-\mathrm{CH}_{2}$ ), at $\delta$ high field of $1.25 \mathrm{ppm}\left(\mathrm{CH}_{2}\right)$ and signals at $\delta 0.88 \mathrm{ppm}\left(\mathrm{CH}_{3}\right.$ groups $)$ suggest dioctyl phthalate (DOP), which has been reported by others (Cruz-Ramírez et al., 2015; LópezSaiz et al., 2014; García-Romo et al., 2018).
On the other hand, signals (ppm) on $5.33(\mathrm{~m}), 2.83(\mathrm{~m}), 2.35(t, \mathrm{~J}=7.5 \mathrm{~Hz}, 3 \mathrm{H})$ $2.03(\mathrm{~m})$ suggested the presence of eicosapentaenoic acid (EPA), and they are in accordance with those reported in the literature (Tyl, Brecker, \& Wagner, 2008) At this stage, results suggested the presence of DOP and EPA in M.11.B; however, other signals were also detected. 
Likewise, signals that appeared at $\delta=9.77(s) \mathrm{ppm}$; associated to hydroxyl groups, $\delta=7.54(d), 7.36(d)$ and $7.13(d d)$ ppm; related to protons of substituted aromatic rings, signals at $\delta=3.8-3.4(\mathrm{~m}) \mathrm{ppm}$; belong to aliphatic protons, and that at $\delta=$ $1.15(d) \mathrm{ppm}$; associated to methyl protons, were also observed. The signals in ${ }^{1} \mathrm{H}-$ NMR spectrum of the proposed molecule presenting the activity show signals in the aromatic region as in the aliphatic region. The complex coupling pattern of the signals that appear in the aromatic region indicate that there is a trisubstituted type aromatic ring of type $1,2,4$. The signals in the region 3-4 ppm indicate that the protons are attached electronegative elements such as oxygen or nitrogen.

Table $4{ }^{1} \mathrm{H}-\mathrm{NMR}$ spectra of sub-fraction M.11.B in $\mathrm{CDCl}_{3}$ at $400 \mathrm{~Hz}$.

\begin{tabular}{|c|c|c|c|c|c|}
\hline \multicolumn{2}{|c|}{$\begin{array}{l}\text { Dioctyl phthalate } \\
\text { (DOP) }\end{array}$} & \multicolumn{2}{|c|}{$\begin{array}{l}\text { Eicosapentaenoic acid } \\
\text { (EPA) }\end{array}$} & \multicolumn{2}{|c|}{$\begin{array}{l}\text { Indolocarbazole alkaloids derivative } \\
\text { (IAD) }\end{array}$} \\
\hline No. & $\delta_{H}$ & No. & $\delta_{H}$ & No. & $\delta_{H}$ \\
\hline 2 & $7.71(\mathrm{dd}, \mathrm{J}=5.7,3.3 \mathrm{~Hz}, 2 \mathrm{H})$ & $5,6,8,9,11$ & & 18 & $9.77(\mathrm{~s}, 2 \mathrm{H})$ \\
\hline 1 & $7.53(\mathrm{dd}, \mathrm{J}=5.7,3.3 \mathrm{~Hz}, 2 \mathrm{H})$ & $12,14,15,17$ & $5.35(\mathrm{~m}, 10 \mathrm{H})$ & 9 & $7.54(\mathrm{~d}, \mathrm{~J}=8.7 \mathrm{~Hz}, 2 \mathrm{H})$ \\
\hline 5 & $4.22(\mathrm{~m}, 4 \mathrm{H})$ & 18 & & 6 & $7.36(\mathrm{~d}, \mathrm{~J}=2.1 \mathrm{~Hz}, 2 \mathrm{H})$ \\
\hline $\begin{array}{l}6,7,8 \\
9,11\end{array}$ & $1.25(\mathrm{~s}, 18 \mathrm{H})$ & $\begin{array}{l}4,7,10,13 \\
16,19\end{array}$ & $2.83(\mathrm{~m}, 12 \mathrm{H})$ & $\begin{array}{c}8 \\
12,13,14\end{array}$ & $\begin{array}{c}7.13(\mathrm{dd}, \mathrm{J}=8.8,2.6 \mathrm{~Hz}, 2 \mathrm{H}) \\
3.8-3.4(\mathrm{~m}, 5 \mathrm{H})\end{array}$ \\
\hline 10,12 & $0.88(\mathrm{~m}, 12 \mathrm{H})$ & $\begin{array}{l}2 \\
4\end{array}$ & $\begin{array}{c}2.35(\mathrm{t}, \mathrm{J}=7.5 \mathrm{~Hz}, 3 \mathrm{H}) \\
2.03(\mathrm{~m}, 2 \mathrm{H})\end{array}$ & 15 & $1.15(\mathrm{~d}, \mathrm{~J}=6.28 \mathrm{~Hz}, 6 \mathrm{H})$ \\
\hline
\end{tabular}

In addition, results from ESI-MS, in negative mode (Fig. 4), indicated a molecular weight of $540.06 \mathrm{~m} / \mathrm{z}$, which is not consisting of neither with DOP or EPA, which indicates that the signal observed possibly corresponds to an indolocarbazole alkaloid derivative (IAD). Considering the signals observed in the NMR spectrum and the observed molecular weight found, it suggests symmetry in the molecule. The shape of the signals in the aromatic region coincides with those in Arcyriaflavin C (Kotha, Saifuddin, \& Aswar, 2016; Nakatani et al., 2003; Steglich, Steffan, Kopanski, \& Eckhardt, 1980). Based on the information obtained by the different spectroscopic data the molecules suggested as components of M.11.B (Fig. 5). Table 4 shows the chemical shifts as well as the integrals of the signals observed in the NMR spectrum.

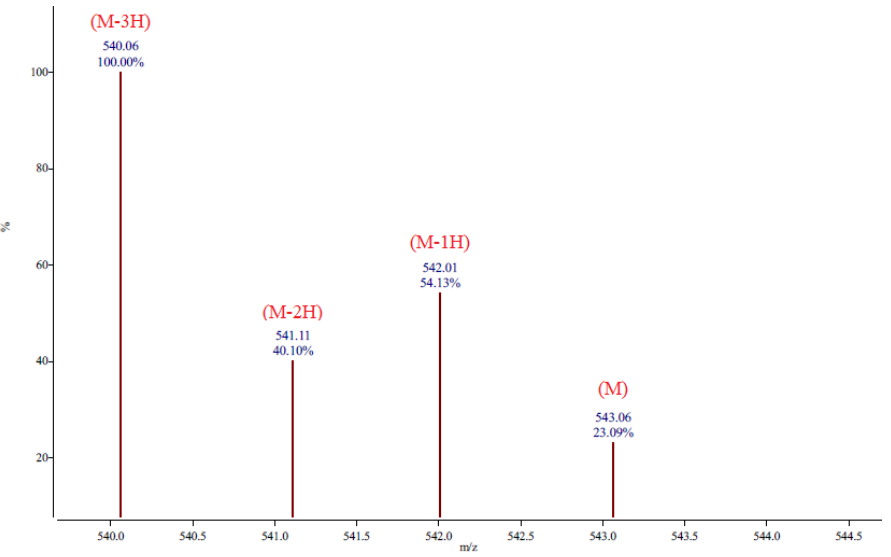

Figure 4 Mode negative ESI /MS of sub-fraction M.11.B, pointing the mass charge of IAD and their isotopes $(\mathrm{M}-\mathrm{H})$<smiles>CCCCCC(CC)COC(=O)c1ccccc1C(=O)OCC(CC)CCC</smiles>

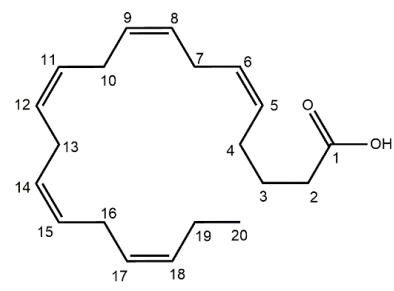

DOP

EP

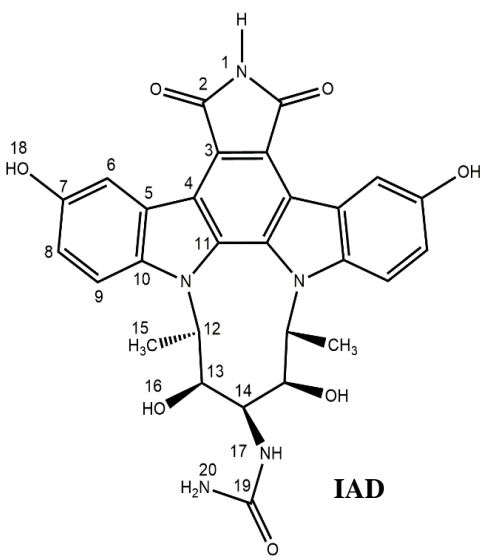

Figure 5 Compounds present in sub-fraction M.11.B based on structural chemical characterization.
The molecule proposed as representative of antiproliferative activity is 1 ((5S,7r,9R)-2,6,8,12-tetrahydroxy-5,9-dimethyl-14,16-dioxo-6,7,8,9,15,16hexahydro-5H,14H-4b,9a,15 triazadibenzo [b, h] cyclonona [jkl] cyclopenta [e] as-indacen-7-yl) urea (IUPAC nomenclature), with chemical formula $\mathrm{C}_{28} \mathrm{H}_{25} \mathrm{~N}_{5} \mathrm{O}$ and with mass of $543 \mathrm{Da}$, this molecule has the characteristics of a new indolocarbazole alkaloid derivative (IAD). The molecule contains atoms of nitrogen related to alkaloid compounds, presenting heterocyclic aromatic organic rings characteristic of the indoles, these are commonly present in natural ecosystems and can be produced by a wide variety of bacteria; being structures derived from the indoles, the indocarbazoles.

On the other hand, chemical structures derived from them and biologically active are the arcyriaflavin, whose molecule is structural base (substituted or not) of the compound isolated in the sample of shrimp; arcyriaflavin is a compound that is structurally related to staurosporine. The staurosporine, is a chemical structures similar to our molecule present in M.11.B, example of these with anticancer activity are: 7-oxo-3, 8, 9-trihidroxiestaurosporine (more similarity with our molecule) and 7-oxo -8, 9-dihydroxy-4'-N demethystastaporine which are present in the ascidia marine Cystodytes solitus and both showed cytotoxicity to cell lines HT-29, A549, and MDA-MB-231 (Reyes et al., 2008), as well as isolated in higher organisms (Jimenez et al., 2012). Therefore, indolocarbazole are a group of structures currently being studied because of their anticancer potential, as well as to the extensive and possible number of derivatives from them; since then, a many molecules have been found throughout the planet, as well as their important use and applications (Sánchez, Méndez, \& Salas, 2006; Wang, Zhang, Li, Ding, \& Ma, 2018); and as we know there is an extensive list of indole alkaloids type of molecules that have been isolated from different marine organisms whit bioactivity potential (Netz \& Opatz, 2015).

\section{Antiproliferative activity of sub-fraction M.11.B.1 and bioselectivity}

Chemical / structural characterization carried out on fraction M.11.B allowed the identification of 2 of at least three compounds present in this fraction; therefore, they were commercially obtaining and tested for bioactivity confirmation (Table 3). Resulting for DOP $\left(\mathrm{GI}_{50}\right.$ greater than $200 \mu \mathrm{g} / \mathrm{ml}$ ) against $22 \mathrm{Rv} 1$ cell line suggested that DOP does not contribute to M.11.B antiproliferative activity. On the other hand, a $\mathrm{GI}_{50}=58.3 \pm 10 \mu \mathrm{g} / \mathrm{ml}$ value obtained for EPA indicated contribution of this compound to M.11.B bioactivity. Other studies have reported similar $\mathrm{GI}_{50}$ values for EPA (Chiu \& Wan, 1999; Lai, Ross, Fearon, Anderson, \& Carter, 1996; Li, Hou, Yeh, \& Yeh, 2017; Turan, Kaya, \& Erdem, 2011) However, by being this $\mathrm{GI}_{50}$ value higher than that obtained for M.11.B, the presence of a third more active compound is suggested. As an additional test, M.11.B was partially purified by removing DOP as much as possible with a wash with ethyl ether (10:1 DMSO v/v), and the resulted purified fraction (M.11.B.1) was tested again for bioactivity.

Sub-fraction M.11.B.1 showed the highest antiproliferative activity (Table 3), showing a $\mathrm{GI}_{50}=26.6 \pm 8 \mu \mathrm{g} / \mathrm{mL}$; according to American National Cancer Institute (NCI) criteria, the $\mathrm{GI}_{50}$ limit value of a crude extract to be considered worthy for further purification is $<30 \mu \mathrm{g} / \mathrm{mL}$ (Upper limit) (Abdel-Hameed, Bazaid, Shohayeb, El-Sayed \& El-Wakil, 2012).

Bioselectivity index (BI) is the term is used to refer to an agent that exhibits a difference growth inhibitory effect between normal and cancerous cell lines. An agent is labeled as "bioselective" if it shows a ratio of at least 3 times its value between its $\mathrm{GI}_{50}$ of normal and cancerous cells (Ciavatta et al., 2017). In this case, the sub-fraction M.11.B.1 was bioselective against 22Rv1 cell line (Table 3); the BI was 6.77 , and it has been established that the higher the BI, a greater chance has the agent of being effective on cancerous cells without harming non-cancerous cells.

Growth kinetics allows us to determine the number of cells affected by M.11.B.1; once the dose-response relationship is obtained, the number of affected (dead/ inhibited) cells by a certain concentration (at a determined time of incubation under stimulus) can be determined. This was obtained for 22Rv1 cell line in $10 \%$ FBS (Fig. 1). The effective concentration (EC) is the proportion of a substance in a 
medium that causes a certain effect in each model (cells); the number of prostate cancer cells obtained after $48 \mathrm{~h}$ of incubation were 32500 , meaning that 22500 cells proliferated in $48 \mathrm{~h}$ since 10000 cells were seeded. Therefore, the EC to affect 50 $\%\left(\mathrm{EC}_{50}\right)$ of cell growth $(11250$ cells $)$ is $26.6 \pm 8 \mu \mathrm{g} / \mathrm{mL}$, considering this as antiproliferation.

To obtain inhibition values equal or lower than 10000 cells on in vitro proliferation systems, we would be talking about cytostatic and cytotoxic terms, like total growth inhibition (TGI), which refers to $0 \%$ of proliferations cells $(22500)$ and lethal concentration medium $\left(\mathrm{LC}_{50}\right)$ that refers to $-50 \%$ of viable cells $(<10000$ which refers to the number of cells seeded), respectively (Boyd \& Paull, 1995), whose required concentrations to these values are greater than $200 \mu \mathrm{g} / \mathrm{mL}$.

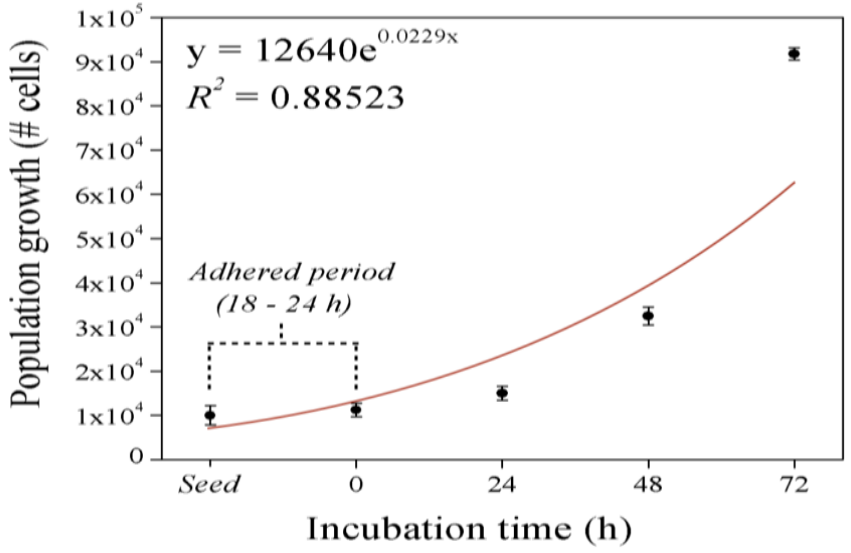

Figure 1 Growth kinetics of 22Rv1 cell line (human prostate epithelial carcinoma) Values represent means \pm S.D. from 3 determinations. Cells were plated in medium RPMI-1640 with $10 \%$ FBS. These means optimal growth, when the cells were incubated in the presence of DMSO $(0.5 \%)$, representing $100 \%$ proliferation on assays.

According to the ATCC, the 22Rv1 (ATCC $(\mathrm{R})$ CRL-2505 ${ }^{\mathrm{TM}}$ ) cell line, is a human epithelial prostate and tumorigenic carcinoma (possessing an androgen receptor), which is stimulated by epidermal growth factor (EGF); however, transforming growth factor beta-1 (TGF beta- 1) does not inhibit it. Moreover, the compounds could be conducting an antiproliferative activity by means of this receptor, this if the extrinsic pathway were considered; however, another way of action would be the intrinsic or mitochondrial pathway where it is related to oxidative stress (Kroemer et al., 2009). To make it clear, according to the $\mathrm{GI}_{50}$ obtained for the rest of the fractions by the Probit test, they are not worthy to be further investigated for bioactivity since their $\mathrm{GI}_{50}$ do not meet the NCI criteria for the development of drugs (Boyd \& Paull, 1995; Chakravarti \& Klopman, 2008)

\section{Cell morphology changes induced by sub-fraction M.11.B.1}

The purpose of this part of the current study was to observe the effects that M.11.B.1 has on cell structure and how these possibly might be related to cell death. Cell morphology changes induced by M.11.B.1 were discussed based on observations made after staining cells F-actin and nuclear material, using fluorescence microscopy; results are shown the in Fig. 2. Cells treated with $26.6 \pm$ $8 \mu \mathrm{g} / \mathrm{mL}$ M.11.B.1 showed, after $4 \mathrm{~h}$ of exposure, cellular structures morphologically similar to those of control, which were cultured only in the presence of DMSO $(<0.5 \%)$. DNA staining with DAPI allowed the observation of cellular damages such as chromatin condensation and nuclear shrinkage (also called pyknosis); moreover, in most cells, DNA diffusion (karyolysis) was observed and, in other cells, karyorrhexis was observed as well, being both phenomena associated to DNA fragmentation. These morphological issues are characteristic of cells that undergoing dead pathways.

Different from control cells, in those treated with M.11.B.1 a decrease in the cell volume (shrinkage) was observed. Large plasma membrane protrusion (blebs) in 22Rv1 cells resulted from F-actin polymerization, which is associated to cell collapse (Coleman et al., 2001; Taylor, Cullen, \& Martin, 2008; Wickman, Julian, \& Olson, 2012). Likewise, microtubule spike and beaded apoptopodia, and apoptotic bodies, which have been associated to cell fragmentation (Poon $\boldsymbol{e t}$ al., 2014; Rubartelli, Poggi, \& Zocchi, 1997; Witasp et al., 2007), were also observed. Results suggest that only a certain percentage of cells were in apoptotic processes, since plasma membrane rupture (which is associated to cellular and nuclear lysis as well as to necrosis pathways) could not be distinguished in cells. However, more studies are recommended to determine the proportions of cells that undergo either pathway.

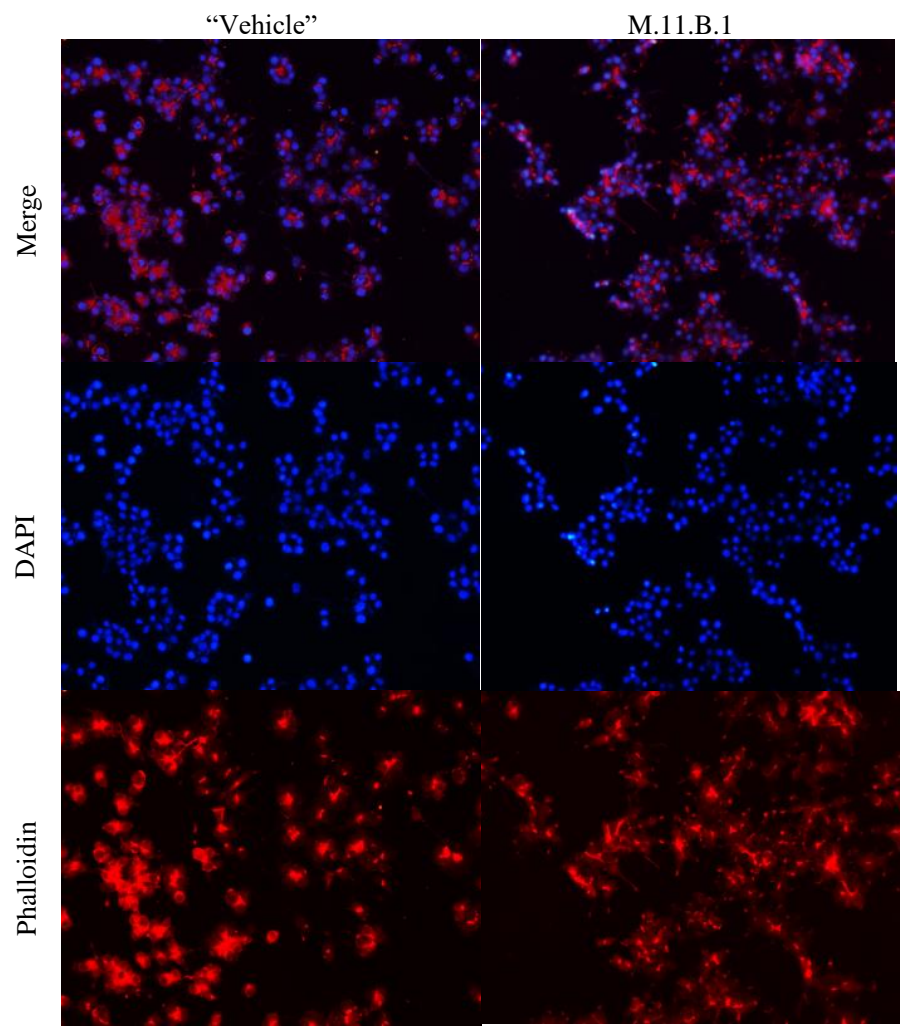

Figure 2 Effect of sub-fraction M.11.B.1 on 22Rv1 cell line (human prostate epithelial carcinoma) morphology changes after $4 \mathrm{~h}$ of incubation. Cell line $22 \mathrm{Rv} 1$ treated with solvent (DMSO to $0.5 \%$ ) only was considered the negative control ("Vehicle"). Fraction M.11.B.1 at $\mathrm{GI}_{50}(26.6 \pm 8 \mu \mathrm{g} / \mathrm{mL})$ was used as the treatment DNA (blue) and actin cytoskeleton (red) were observed by DAPI and phalloidintetramethylrhodamine B isothiocyanate staining, respectively. The cells were observed at $20 \mathrm{x}$.

These results are evidence that the compound present in M.11.B.1 responsible for decreasing cancerous cell population, and possibly for inducing apoptosis on prostate carcinoma in vitro, is another one in addition to carotenoids, a triglyceride esterified containing PUFAs or even free PUFAs (compounds already reported in several previous studies). A general diagram of the bioassay guided isolation and the identification of the IAD extracted from $L$. vannamei with in vitro anticance potential is shown in Fig. 6. In addition, recently, antihemolysis, antioxidant and retinoprotective potential activities have been reported for these same compounds (García-Romo, et al., 2020) which suggests that, in addition to reduce proliferation of cancerous cells, they may also act in a protective way at the same time.

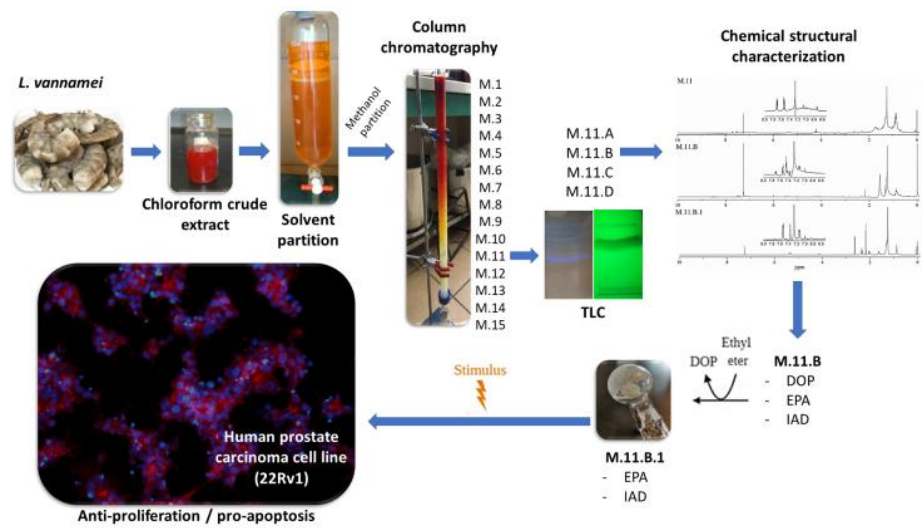

Figure 6 General diagram of the bio-assay guided isolation from farmed shrimp (Litopenaeus vannamei) muscle.

\section{CONCLUSIONS}

The present study demonstrated that the antiproliferative effect of M.11.B.1 on a prostate cancerous cell line is, in addition to EPA, majorly caused by another compound yet to be fully characterized (IAD). Also, this compound possibly has the capability of inducing cellular collapse associated to apoptosis. These findings open the possibility of chemically synthesize IAD and test it in its pure form in order to biochemically understand its possible beneficial effect on health and be proposed as potential chemotherapeutic agents. However, further investigation is 
needed to confirm the apoptotic activity of components of M.11.B.1; specifically, early and late apoptosis by annexin- $\mathrm{V} /$ propidium iodide, activation of intrinsic and extrinsic caspases, and even alteration of oxidative stress by ROS (2 ', 7'Dichlorodihydrofluorescein, a fluorescent probe).

Acknowledgments: Authors acknowledge the Consejo Nacional de Ciencia y Tecnología (CONACYT) México for granting graduate scholarship and financial support to project 241133

\section{REFERENCE}

Abdel-Hameed, E. S. S., Bazaid, S. A., Shohayeb, M. M., El-Sayed, M. M., \& ElWakil, E. A. (2012). Phytochemical studies and evaluation of antioxidant, anticancer and antimicrobial properties of Conocarpus erectus L. growing in Taif, Saudi Arabia. European Journal of Medicinal Plants, 2(2), 93. https://doi:10.9734/EJMP/2012/1040

Austreid, E., Lonning, P. E., \& Eikesdal, H. P. (2014). The emergence of targeted drugs in breast cancer to prevent resistance to endocrine treatment and chemotherapy. Expert Opinion on Pharmacotherapy. https://doi.org/10.1517/14656566.2014.885952

Boyd, M. R., \& Paull, K. D. (1995). Some practical considerations and applications of the national cancer institute in vitro anticancer drug discovery screen. Drug Development Research, 34(2), 91-109. https://doi.org/10.1002/ddr.430340203 Buzdar, A. U., Ibrahim, N. K., Francis, D., Booser, D. J., Thomas, E. S., Theriault, R. L., ... Hortobagyi, G. N. (2005). Significantly higher pathologic complete remission rate after neoadjuvant therapy with trastuzumab, paclitaxel, and epirubicin chemotherapy: results of a randomized trial in human epidermal growth factor receptor 2-positive operable breast cancer. Journal of Clinical Oncology, 23(16), 3676-3685. https://doi.org/10.1200/JCO.2005.07.032

Chakravarti, S. K., \& Klopman, G. (2008). A structural analysis of the differential cytotoxicity of chemicals in the NCI-60 cancer cell lines. Bioorganic and $\begin{array}{lll}\text { Medicinal Chemistry, } & \text { 16(7), }\end{array}$ https://doi.org/10.1016/j.bmc.2008.01.024

Chiu, L. C. M., \& Wan, J. M. F. (1999). Induction of apoptosis in HL-60 cells by eicosapentaenoic acid (EPA) is associated with downregulation of bcl-2 expression. Cancer Letters, 145(1-2), 17-27. https://doi.org/10.1016/S03043835(99)00224-4

Ciavatta, M. L., Lefranc, F., Carbone, M., Mollo, E., Gavagnin, M., Betancourt, T., ... Kiss, R. (2017, July 1). Marine mollusk-derived agents with antiproliferative activity as promising anticancer agents to overcome chemotherapy resistance. Medicinal Research Reviews. John Wiley \& Sons, Ltd. https://doi.org/10.1002/med.21423

Coleman, M. L., Sahai, E. A., Yeo, M., Bosch, M., Dewar, A., \& Olson, M. F. (2001). Membrane blebbing during apoptosis results from caspase-mediated activation of ROCK I. Nature Cell Biology, 3(4), 339-345. https://doi.org/10.1038/35070009

Cruz-Ramírez, S. G., López-Saiz, C. M., Plascencia-Jatomea, M., Machi-Lara, L., Rocha-Alonzo, F., Márquez-Ríos, E., \& Burgos-Hernández, A. (2015). Isolation and identification of an antimutagenic phthalate derivative compound from octopus (Paraoctopus limaculatus). Tropical Journal of Pharmacentical Research, 14(7), 1257-1264. https://doi.org/10.4314/tjpr.v14i7.19

De Kok, T. M., Van Breda, S. G., \& Manson, M. M. (2008). Mechanisms of combined action of different chemopreventive dietary compounds: A review European Journal of Nutrition. D. Steinkopff-Verlag. https://doi.org/10.1007/s00394-008-2006-y

DeVita, V. T., \& Chu, E. (2008). A history of cancer chemotherapy. Cancer Research. American Association for Cancer Research. https://doi.org/10.1158/0008-5472.CAN-07-6611

García-Romo, J. S., Noguera-Artiaga, L., Gálvez-Iriqui, A. C., HernándezZazueta, M. S., Valenzuela-Cota, D. F., González-Vega, R. I., ... \& BurgosHernández, A. (2020). Antioxidant, antihemolysis, and retinoprotective potentials of bioactive lipidic compounds from wild shrimp (Litopenaeus stylirostris) muscle.
CyTA-Journal$$
\text { of Food }
$$
$18(1)$
153-163.

https://doi.org/10.1080/19476337.2020.1719210

García-Romo, J. S., Susana Yepiz-Gomez, M., Plascencia-Jatomea, M., del Carmen Santacruz-Ortega, H., Burgos-Hernandez, A., de Leon, J. R., ... BorboaFlores, J. (2018). Compounds with in vitro antibacterial activity from hydrosol of lippia palmeri and morphometric changes on Listeria monocytogenes. biotecnia, 20(3), 35-42. https://biotecnia.unison.mx/index.php/biotecnia/article/view/713 Jimenez, P. C., Wilke, D. V., Ferreira, E. G., Takeara, R., De Moraes, M. O., Silveira, E. R., ... Costa-Lotufo, L. V. (2012). Structure elucidation and anticancer activity of 7-oxostaurosporine derivatives from the Brazilian endemic tunicate Eudistoma vannamei. Marine Drugs, 10(5), 1092-1102. https://doi.org/10.3390/md10051092

Kotha, S., Saifuddin, M., \& Aswar, V. R. (2016). A diversity-oriented approach to indolocarbazoles: via Fischer indolization and olefin metathesis: Total synthesis of tjipanazole D and i. Organic and Biomolecular Chemistry, 14(41), 9868-9873. https://doi.org/10.1039/c6ob01679k

Kroemer, G., Galluzzi, L., Vandenabeele, P., Abrams, J., Alnemri, E. S., Baehrecke, E. H., ... Melino, G. (2009). Classification of cell death:
Recommendations of the nomenclature committee on cell death 2009. Cell Death and Differentiation. Nature Publishing Group. https://doi.org/10.1038/cdd.2008.150

Lai, P. B. S., Ross, J. A., Fearon, K. C. H., Anderson, J. D., \& Carter, D. C. (1996) Cell cycle arrest and induction of apoptosis in pancreatic cancer cells exposed to eicosapentaenoic acid in vivo. British Journal of Cancer, 74(9), 1375-1383. https://doi.org/10.1038/bjc.1996.552

Li, C. C., Hou, Y. C., Yeh, C. L., \& Yeh, S. L. (2017). Retraction: Effects of eicosapentaenoic acid and docosahexaenoic acid on prostate cancer cell migration and invasion induced by tumor-associated macrophages. PloS One. https://doi.org/10.1371/journal.pone.0173325

Liu, K., Xiao, X., Wang, J., Chen, C.-Y. Y. O., \& Hu, H. (2017). Polyphenolic composition and antioxidant, antiproliferative, and antimicrobial activities of mushroom Inonotus sanghuang. LWT - Food Science and Technology, 82, 154161. https://doi.org/10.1016/j.lwt.2017.04.041

Liu, S., Zheng, L., Aweya, J. J., Zheng, Z., Zhong, M., Chen, J., ... Zhang, Y. (2017). Litopenaeus vannamei hemocyanin exhibits antitumor activity in S180 mouse model in vivo. PLoS ONE, 12(8), e0183783. https://doi.org/10.1371/journal.pone.0183783

Liu, W., Wang, L., Wang, B., Xu, Y., Zhu, G., Lan, M., ... Sun, K. (2019). Diketopiperazine and diphenylether derivatives from marine algae-derived Aspergillus versicolor OUCMDZ-2738 by epigenetic activation. Marine Drugs, 17(1), 6. https://doi.org/10.3390/md17010006

Livstone, E. M. (2019). Colorectal cancer (colon cancer) - Merck Manual, Professional Version. https://doi.org/10.3322/caac.21387

López-Saiz, C. M., Hernández, J., Cinco-Moroyoqui, F. J., Velázquez, C., OcañoHiguera, V. M., Plascencia-Jatomea, M., ... Burgos-Hernández, A. (2016) Antimutagenic compounds of white shrimp (Litopenaeus vannamei): Isolation and structural elucidation. Evidence-Based Complementary and Alternative Medicine 2016, 1-7. https://doi.org/10.1155/2016/8148215

López-Saiz, C. M., Suárez-Jiménez, G. M., Plascencia-Jatomea, M., \& BurgosHernández, A. (2013). Shrimp lipids: A source of cancer chemopreventive compounds. Marine Drugs. Multidisciplinary Digital Publishing Institute https://doi.org/10.3390/md11103926

López-Saiz, C. M., Velázquez, C., Hernández, J., Cinco-Moroyoqui, F. J., Plascencia-Jatomea, M., Robles-Sánchez, M., ... Burgos-Hernández, A. (2014). Isolation and structural elucidation of antiproliferative compounds of lipidic fractions from white shrimp muscle (Litopenaeus vannamei). International Journal of Molecular Sciences, 15(12), 23555-23570. https://doi.org/10.3390/ijms151223555

Lordan, S., Ross, R. P., \& Stanton, C. (2011). Marine bioactives as functional food ingredients: Potential to reduce the incidence of chronic diseases. Marine Drugs. Molecular Diversity Preservation International https://doi.org/10.3390/md9061056

Martin, M., Brase, J. C., Calvo, L., Krappmann, K., Ruiz-Borrego, M., Fisch, K., . Rodriguez-Lescure, A. (2014). Clinical validation of the EndoPredict test in node-positive, chemotherapy-treated ER+/HER2- breast cancer patients: Results from the GEICAM 9906 trial. Breast Cancer Research, 16(2), R38. https://doi.org/10.1186/bcr3642

Monks, A., Scudiero, D., Skehan, P., Shoemaker, R., Paull, K., Vistica, D., .. Boyd, M. (1991). Feasibility of a high-flux anticancer drug screen using a diverse panel of cultured human tumor cell lines. Journal of the National Cancer Institute, 83(11), 757-766. https://doi.org/10.1093/jnci/83.11.757

Nakatani, S., Naoe, A., Yamamoto, Y., Yamauchi, T., Yamaguchi, N., \& Ishibashi, M. (2003). Isolation of bisindole alkaloids that inhibit the cell cycle from Myxomycetes Arcyria ferruginea and Tubifera casparyi. Bioorganic and Medicinal Chemistry Letters, 13(17), 2879-2881. https://doi.org/10.1016/S0960894X(03)00592-4

Netz, N., \& Opatz, T. (2015). Marine indole alkaloids. Marine Drugs, 13(8), 4814 4914. https://doi.org/10.3390/md13084814

Poon, I. K. H., Chiu, Y. H., Armstrong, A. J., Kinchen, J. M., Juncadella, I. J., Bayliss, D. A., \& Ravichandran, K. S. (2014). Unexpected link between an antibiotic, pannexin channels and apoptosis. Nature, 507(7492), 329-334. https://doi.org/10.1038/nature13147

Reyes, F., Fernández, R., Rodríguez, A., Bueno, S., De Eguilior, C., Francesch, A., \& Cuevas, C. (2008). Cytotoxic staurosporines from the marine ascidian Cystodytes solitus. Journal of Natural Products, 71(6), 1046-1048. https://doi.org/10.1021/np700748h

Rubartelli, A., Poggi, A., \& Zocchi, M. R. (1997). The selective engulfment of apoptotic bodies by dendritic cells is mediated by the $\alpha v \beta 3$ integrin and requires intracellular and extracellular calcium. European Journal of Immunology, 27(8), 1893-1900. https://doi.org/10.1002/eji.1830270812

Sánchez, C., Méndez, C., \& Salas, J. A. (2006). Indolocarbazole natural products: Occurrence, biosynthesis, and biological activity. Natural Product Reports. https://doi.org/10.1039/B601930G

Sila, A., Ayed-Ajmi, Y., Sayari, N., Nasri, M., Martinez-Alvarez, O., \& Bougatef, A. (2013). Antioxidant and Anti-proliferative activities of astaxanthin extracted from the shell waste of deep-water pink shrimp (Parapenaeus longirostris). The $\begin{array}{lllr}\text { Natural Products } & \text { Journal, } & 3(2), & 82-89 .\end{array}$ https://doi.org/10.2174/2210315511303020002 
Sowmya, P. R. R., Arathi, B. P., Vijay, K., Baskaran, V., \& Lakshminarayana, R. (2017). Astaxanthin from shrimp efficiently modulates oxidative stress and allied cell death progression in MCF-7 cells treated synergistically with $\beta$-carotene and lutein from greens. Food and Chemical Toxicology, 106, 58-69. https://doi.org/10.1016/j.fct.2017.05.024

Stankevicins, L., Aiub, C., Maria, L. C. C. d. S., Lobo-Hajdu, G., \& Felzenszwalb, I. (2008). Genotoxic and antigenotoxic evaluation of extracts from Arenosclera brasiliensis, a Brazilian marine sponge. Toxicology in Vitro, 22(8), 1869-1877. https://doi.org/10.1016/j.tiv.2008.09.003

Steglich, W., Steffan, B., Kopanski, L., \& Eckhardt, G. (1980). Indole Pigments from the Fruiting Bodies of the Slime Mold Arcyria denudata. Angewandte Chemie International Edition in English, 19(6), 459-460. https://doi.org/10.1002/anie.198004591

Taylor, R. C., Cullen, S. P., \& Martin, S. J. (2008). Apoptosis: Controlled demolition at the cellular level. Nature Reviews Molecular Cell Biology. Nature Publishing Group. https://doi.org/10.1038/nrm2312

Thomson, C. A., LeWinn, K., Newton, T. R., Alberts, D. S., \& Martinez, M. E. (2003). Nutrition and diet in the development of gastrointestinal cancer. Current Oncology Reports. Current Medicine Group. https://doi.org/10.1007/s11912-0030110-y

Turan, H., Kaya, Y., \& Erdem, M. E. (2011). Proximate composition, cholesterol, and fatty acid content of brown shrimp (Crangon crangon L. 1758) from Sinop region, Black Sea. Journal of Aquatic Food Product Technology, 20(1), 100-107. https://doi.org/10.1080/10498850.2010.526753

Tyl, C. E., Brecker, L., \& Wagner, K. H. (2008). 1H NMR spectroscopy as tool to follow changes in the fatty acids of fish oils. European Journal of Lipid Science and Technology, 110(2), 141-148. https://doi.org/10.1002/ejlt.200700150

Van Vuuren, R. J., Botes, M., Jurgens, T., Joubert, A. M., \& Van Den Bout, I. (2019). Novel sulphamoylated 2-methoxy estradiol derivatives inhibit breast cancer migration by disrupting microtubule turnover and organization 06 Biological Sciences 0601 Biochemistry and Cell Biology. Cancer Cell International, 19(1), 1. https://doi.org/10.1186/s12935-018-0719-4

Wang, J. N., Zhang, H. J., Li, J. Q., Ding, W. J., \& Ma, Z. J. (2018). Bioactive Indolocarbazoles from the Marine-Derived Streptomyces sp. DT-A61. Journal of Natural Products, 81(4), 949-956. https://doi.org/10.1021/acs.jnatprod.7b01058

Wickman, G., Julian, L., \& Olson, M. F. (2012). How apoptotic cells aid in the removal of their own cold dead bodies. Cell Death and Differentiation. Nature Publishing Group. https://doi.org/10.1038/cdd.2012.25

Wilson-Sanchez, G., Moreno-Félix, C., Velazquez, C., Plascencia-Jatomea, M., Acosta, A., Machi-Lara, L., ... Burgos-Hernandez, A. (2010). Antimutagenicity and antiproliferative studies of lipidic extracts from white shrimp (Litopenaeus vannamei). Marine Drugs, 8(11), 2795-2809. https://doi.org/10.3390/md8112795

Witasp, E., Uthaisang, W., Elenström-Magnusson, C., Hanayama, R., Tanaka, M. Nagata, S., ... Fadeel, B. (2007). Bridge over troubled water: Milk fat globule epidermal growth factor 8 promotes human monocyte-derived macrophage clearance of non-blebbing phosphatidylserine-positive target cells [2]. Cell Death and Differentiation. Nature Publishing Group. https://doi.org/10.1038/sj.cdd.4402096

Zheng, L., Zhao, X., Zhang, P., Chen, C., Liu, S., Huang, R., ... Zhang, Y. (2016). Hemocyanin from shrimp litopenaeus vannamei has antiproliferative effect against hela cell in vitro. PloS One, 11(3), e0151801. https://doi.org/10.1371/journal.pone.0151801 